\title{
The Study of Condition Financial and Credit Institutions in Iran: Perspective and History
}

\author{
Niavand $\mathrm{H}^{1 *}$ and $\mathrm{Nia} \mathrm{FH}^{2}$ \\ ${ }^{1}$ Department of Business Administration (BIMS), University of Mysore, Mysore, Karnataka, India \\ ${ }^{2}$ Department of studies in Commerce, University of Mysore, Mysore, Karnataka, India
}

\begin{abstract}
In this article examine that conditions of financial and credit institutions in Iran, Credit institutions; non-governmental and public economic institutions in Iran agreed in principle with the central bank are established and engaged in banking operations. Credit union institution that by attracting deposits allowed the bank (excluding deposit interest-free loan current), obtaining loans and other financial instruments to mobilize resources. Venture and the resources to grant credit facilities assigned or in any other manner to recognition of the central bank, intermediary between suppliers and applicants have the financial resources. We will check, now condition of financial and credit institutions is possible or not, and the result will be institutions offering appropriate solutions.
\end{abstract}

Keywords: Financial and credit institutions; Central bank; Economic crises

\section{Introduction}

Today, banks play a crucial role in global economic development in countries, an institution that provides a great variety of financial services. The role of financial mediation in the economy, regardless of the market-oriented or bank-oriented economy, is of considerable importance. At market-oriented economies, recessions or prosperity in the financial sector lead to stagnation or prosperity in the real sector of the economy. In this between banks, as intermediaries, financial intermediaries carry out operations such as maturity intermediation, risk mediation, intermediation interest rates. Meanwhile, the complexity of laws and regulations by banks or financial and credit institutions as well as supervision is one of the main challenges of the banking system. In addition, the central bank plays an important role in reforming the law they have transparency.

At their most fundamental, banks hold cash in the interest of clients, which is payable to the client on request, either by showing up at the bank for a withdrawal or by composing a check to an outsider, Banks utilize the cash they hold to back advances, which they make to organizations and people to pay for operations, contracts, instruction costs, and any number of different things. Many banks likewise perform different administrations for an expense; for example they offer ensured checks to clients ensuring instalment to outsiders. In a few nations they may give speculation and protection administrations. Except for Islamic banks, they pay enthusiasm on stores and get enthusiasm on their advances. Banks are directed by the laws and national banks of their nations of origin; typically they should get a sanction to participate in business. Banks are typically sorted out as enterprises.

Nowadays, banks and finance and credit institutions can monitor and control their activities through online links and systems. Using communication technology enables finance and credit institutions to propose up-to-date services, and accordingly present brand-new credit and finance offerings to their customers.

Customers of banks and finance institutions today accomplish their banking activities by using online portals. Therefore, they expect online services, like internet banking, to be available without any disruption in every time and place.

According to the Central Bank of Iran, Minimum capital requirements for credit institutions established in 300 billion USD, according to the bylaws approved by the State Board, 4 February 2015 credit institution after getting Central Bank agreements must be in a three-step of the Bank license (the primary license, certificate, permit, established) but in practice a large number of these institutions without having the license of the Central Bank.

Many economic crises in history have been the result of financial crises, and many financial crises in turn originated as failures of financial intermediaries. And in every instance the reference has been to banks, in their essential role as deposit-taking entities involved primarily in the business of lending.

\section{Background}

Reinhart and Rogoff [1] distinguish exactly thirty separate occasions of keeping money emergencies crosswise over numerous nations and at various focuses in time amid the most recent 100 years. Cantor et al. archive that near $80 \%$ of portfolio supervisors and store supports expressly depend using a loan evaluation in their portfolio rules. Various investigations have demonstrated that over a specific size of money related advancement with respect to the span of the local economy, development in a local monetary part is hindering to total profitability development $[2,3]$. This "vanishing impact" of the budgetary area in late writing has been named the back revile wonder, where development in a money related segment benefits the nations that host it just to a limited degree, past which promote development turns negative. As per Cecchetti and Kharroubi [2], the fund revile marvel happens in light of the fact that the monetary segment contends with whatever is left of the economy for rare assets; thusly, money related blasts are not, as a rule, development improving.

${ }^{*}$ Corresponding author: Hossein Niavand, Research Scholar, Department of Business Administration (BIMS), University of Mysore, Mysore, Karnataka, India, Tel: 0821242 0331; E-mail: niavandd@gmail.com

Received July 26, 2017; Accepted October 12, 2017; Published October 22, 2017

Citation: Niavand H, Nia FH (2017) The Study of Condition Financial and Credit Institutions in Iran: Perspective and History. J Bus Fin Aff 6: 294. doi: 10.4172/21670234.1000294

Copyright: (c) 2017 Niavand H, et al. This is an open-access article distributed under the terms of the Creative Commons Attribution License, which permits unrestricted use, distribution, and reproduction in any medium, provided the original author and source are credited. 
Shen and Lee show a reverse U-formed connection between budgetary improvement and monetary development, where a more elevated amount of money related advancement has a tendency to moderate financial development. The above discoveries of the limit and non-straight connection between budgetary improvement and monetary development highlight an irregularity with the "more fund, more development" suggestion as appeared in past writing.

Beck et al. point out that the growth effect of financial development comes through enterprises rather than households to drive the positive impact.

In 2011, it was completed the organization of 1700 credit cooperatives was, of which there were about 1,500 cooperative companies and 200 cooperatives has been free of charge. At the end of 2011, the deposits absorbed by these cooperatives and cash departments are estimated about 600 thousand billion rials. According to the Minister of Cooperatives, in June 2011, there were deposited, 300 thousand billion rials, It has been open to free credit cooperatives. Thus, from the amount of 600,000 billion rials related to the end of 2011, about 300 Thousand billion Rials of liquidity are under the authority of credit cooperatives [4]. According to the Central Bank, the balance of Rials and foreign exchange deposits of banks and credit institutions in March, 2010 is equivalent to 3.68 million trillion rials. Comparing the character of 600 trillion rials mentioned above with this character which accounts for over $19 \%$ of the banking system's deposits financial and credit institutions [5].

Issued by the head of the central bank, deposits held by financial and credit institutions. It is 850 trillion rials, which can be said to account for $27 \%$ of the banking system deposits in authorities of financial and credit institutions [6]. From the accumulation of about 70 credit cooperatives, there were 14 financial institutions the credit will be continued under the title, and the central bank will monitor its performance with the establishment of a resident observer.

\section{The Problems of Financial and Credit Institutions}

The Iranian economy has been hit by the recession, and in the last two years, various ways have been proposed to break this ring. But the common point of all these solutions is that it should be reformed somehow in the banking system, since the monetary system and banks have not only been contributing to development and a productive economy, which has now become a problem for the economy [7]; they are more vulnerable to being able to count on auxiliary power. However, the dilemma of their deferred claims and interference in different markets and the increase in the amount of money rotation has been a negative service that has come from this network and contributed to unproductive economic networks [8].

The rebellion of this network from the definitive laws of the economy and the monetary and financial supervisory authority of the country (central bank) in recent years has led to the formation of unauthorized banking and financial institutions [9]. Now, the bank's deferred claims are shrinking, and apparently it is not supposed to reduce the burden of these debts.

The rate of profit is one of the challenges in this area that has hit the whole economy [10]. Production has long benefited from the livelihood rate of the flock, and has repeatedly stated that the real production will not be provided with these figures. The government had previously decided to cut interest rates with regard to the same cattle, which, of course, resulted in a photograph. Because unauthorized credit institutions, or the uncooled monetary market, benefit far more than the rates and encourage people to invest and cover their bankruptcy by raising their profits. But in the end, with the issues said, something needs to be done and the accounts of the central bank corrected negatively.

In this regard, the government's efforts to block unauthorized credit institutions and the transformation of authorized institutions into banks have begun, suggesting that the bankruptcy of these institutions has been more serious than before.

\section{Conclusion}

Today, financial and credit institutions are part of the IFC the financial structure is the vast majority of countries in the world, This Institutions are quicker than banks in financial and banking systems as well as market-oriented growth. But now in Iran, there are some causes and disadvantages in financial and credit institutions, include that:

1. Unequal and unhealthy financial and credit institutions with banks and the possibility of absorbing deposits with a rate of profit closer to inflation; in circumstances according to the central bank, the inflation rate is more than 30 percent and there is an expectation of rising inflation in the coming months, attracting a deposit with a maximum allowable interest rate means a negative profit rate.

2. The central bank also needs to revise the policy of interest rates so that the value of small deposits is not reduced and instead, recipients of the facility will not benefit.

3. The need for restructuring and merging together and the formation of one or more new banks or merging with existing banks.

4. In order to develop the country's banking system and outflow from the current situation, that can be used merging banks together or seizing financial and credit institutions and active and unauthorized credit by banks is an appropriate solution.

5. The need to monitor and enforce the laws of financial and credit institutions by the central bank.

6. Given the significant number of banks and financial and credit institutions as well as unauthorized loan funds, it seems that the number of banks and financial and credit institutes is high for the volume of activity of the Iranian economy.

7. For monitor to be placed, you need to regularly report the performance of banks and financial and credit institutions to the central bank.

\section{References}

1. Reinhart CM, Rogoff KS (2008) Is the 2007 US sub-prime financial crisis so different? An international historical comparison. National Bureau of Economic Research, pp: 1-15.

2. Cecchetti SG, Kharroubi E (2012) Reassessing the impact of finance on growth

3. Law SH, Singh N (2014) Does too much finance harm economic growth? Journal of Banking \& Finance 41: 36-44.

4. Central bank of Islamic Republic of Iran (2015) Rules governing the establishment of non-bank credit institutions and practices.

5. Central bank of Islamic Republic of Iran (2015) The minimum capital required for the establishment of credit institutions.

6. Delegation of ministers (2014) Regulations to establish and maintain non-credit institutions. The Iranian government. Central Bank of the Islamic Republic of Iran. 
Citation: Niavand H, Nia FH (2017) The Study of Condition Financial and Credit Institutions in Iran: Perspective and History. J Bus Fin Aff 6: 294. doi: 10.4172/2167-0234.1000294

Page 3 of 3

7. http://financial-dictionary.thefreedictionary.com

8. Monetary and Banking Research Center (2012) Conferences Financial and Credit Institutions, Tehran.
9. Online news (2016) Credit to Deposit How can a financial institution licensed by the Central Bank?

10. Purda L, Sonmez F, Zhong L (2015) Financial institution credit assessment and implications for portfolio managers. Journal of International Financial Markets, Institutions and Money 38: 148-166. 